\title{
Post abortion contraceptive behavior among Indian women
}

\author{
Nutan Kumari, Mili Dutta*, Chander Shekhar
}

Department of Fertility Studies, International Institute for Population Sciences, Mumbai, Maharashtra, India

Received: 09 March 2017

Accepted: 07 April 2017

*Correspondence:

Dr. Mili Dutta,

E-mail: duttamili90@gmail.com

Copyright: () the author(s), publisher and licensee Medip Academy. This is an open-access article distributed under the terms of the Creative Commons Attribution Non-Commercial License, which permits unrestricted non-commercial use, distribution, and reproduction in any medium, provided the original work is properly cited.

\section{ABSTRACT}

Background: Unsafe induced abortion contributes significantly to maternal morbidity and mortality. Irrespective of availability of contraceptive services women still seek for repeated induced abortion. This study examined the contraceptive behavior of currently married women who had induced abortion.

Methods: Third round of District Level Household and Facility Survey (DLHS-3, 2007-2008) data is used for the study. Bivariate analysis and multivariate logistic regression method were used to examine the contraceptive behavior of women.

Results: Contraceptive use is 4.6 percent among women who had at least one induced abortion. Attitude toward the use of contraceptive was found significant among women aged 25-34, who had one and two or more children, urban women, non-poor, couple both literate and women exposed to mass media.

Conclusions: This study suggests the need for proper post-abortion contraception counseling and availability of multiple choices of modern methods of contraceptive among women.

Keywords: Contraceptive behavior, Currently married, India, Induced abortion

\section{INTRODUCTION}

Induced abortion has been practiced in one form or another from the beginning of human society. However, recently the practice of induced abortion appears to have increased significantly in many countries of the world. Estimates indicate that approximately 70 million of the 205 million pregnancies yearly end in abortion. Of these, 42 million are induced abortion. ${ }^{1}$ Of the total induced abortions, a large share takes place in the developing countries using unsafe contraceptive method. ${ }^{2}$ Although decriminalization of abortion feature of evolving the legal system in many parts of the world, the law still restricts induced abortion in many third world countries. ${ }^{3}$

In India, under the 1971 Medical Termination of Pregnancy Act, a woman can legally obtain an induced abortion if her pregnancy can bring the risk of grave physical injury, threatens her mental health, is likely to produce a child with physical or mental abnormalities, is the result of contraceptive failure among married women and rape. ${ }^{4}$ India accounts for 6.4 million induced abortion and approximately 4 million spontaneous abortions each year, most performed in unsafe conditions and often without any contraceptive counseling or services. ${ }^{5-7}$

Although women request abortions for various reasons for these qualitative studies conducted as part of the abortion assessment project across multiple states in 2002 , the majority of unintended pregnancies that were resolved through abortion occurred during periods when few were reportedly due to contraceptive failure. ${ }^{8}$

Non-use of contraception often reflects an inadequate or uneven supply of contraceptive services, particularly temporary by unequal power structures within families that restrict women's access to contraceptive information and services and prevents women from being able to negotiate contraceptive use. ${ }^{9}$ 
In many countries, the pattern of post-abortion contraceptive use differs. In Brazil, the contraceptive acceptance and use are high when post-abortion family planning services are provided. ${ }^{10,11}$ But this is far from reality for the majority of women in countries with restrictive laws toward induced abortion. ${ }^{12}$ In Nigeria, for instance, one-fifth of post-abortion women received family planning counseling, whereas only $3 \%$ received contraceptive method. ${ }^{13}$ The only observational study conducted in Brazil assessed the poor quality of postabortion care, as only $7.9 \%$ of women received a prescription for a contraceptive before hospital discharge. ${ }^{14}$

A study of state Kerala in India reported that the number of induced abortion is increasing every year. Despite a very high female literacy and contraceptive prevalence of more than $60 \%$, many married women opt for abortion to limit their size and for spacing. ${ }^{15}$ The present study is determined to examine the post-abortion contraceptive behavior of currently married women.

\section{METHODS}

For the present study, data has been taken from the third round of District Level Household and Facility Survey (DLHS-3, 2007-2008). DLHS-3 is one of the largest ever demographic and health surveys carried out in India, 0.7 million households covering all with a sample of 7 , 20,320 households from 34 states and union territories of India (excluding Nagaland). From these households, 6, 43,944 ever married women aged 15-49 years and 1, 66,260 unmarried women aged 15-24 years were interviewed. DLHS-3 also provides data on currently married women aged 15-44 years and ever-married women (age 15-49).

The ever-married women's questionnaire sought information on women's characteristics, maternal care, immunization and child care, contraception and fertility preferences, retroactive health including knowledge about RTI/STI and HIV/AIDS. Data were taken on abortion and contraceptive behavior of currently married women $(60,40,804)$ in ages 15 to 49 years; they are used as a proxy in further analysis.

\section{Dependent variable}

The dependent variable for the study is taken as contraception use among currently married women aged 15-49 experienced at least one induced abortion. The contraception use is categorized into two including "nonusing any contraceptive method" and "using any contraceptive method."

\section{Independent variable}

The independent variable taken for the study are agegroup of women (15-24, 25-34, and 35-39), number of children (No child, 1, and 2-3), place of abortion (Public,
Private, and other), place of residence (Rural, Urban), Religion (Hindu, Muslim, and Others), Caste/tribe (Scheduled caste, Scheduled tribe, and Other backward class), Wealth index (Poor, and Not Poor), couples education (Both illiterate, Only husband literate, Only wife literate, and Both literate) and mass media exposure (No exposure, and exposure).

\section{Statistical analysis}

Bivariate analyses were performed to determine the postabortion family planning used, reasons for not using contraception by background characteristics of women and women currently not using prefer to use in future. Multiple logistic regression has performed to identify the key determinants of contraceptive use among currently married women experienced at least one induced abortion.

\section{RESULTS}

Table 1 portrays the percentage distribution of family planning method used by currently married women aged 15-49 years who had gone for induced abortion.

Table 1. Percentage distribution of currently married women aged 15-49 years using family planning method after abortion by type of method.

\begin{tabular}{|lllll|}
\hline $\begin{array}{l}\text { Family } \\
\text { planning } \\
\text { method }\end{array}$ & $\begin{array}{l}\text { Never } \\
\text { had } \\
\text { abortion }\end{array}$ & $\begin{array}{l}\text { One } \\
\text { abortion }\end{array}$ & $\begin{array}{l}\text { More } \\
\text { than } \\
\text { one } \\
\text { abortion }\end{array}$ & $\begin{array}{l}\text { Total } \\
\text { no. }\end{array}$ \\
\hline Permanent* & 0.2 & 0.2 & 0.1 & 575 \\
\hline IUD & 3.1 & 6.2 & 5.3 & 9822 \\
\hline PILL & 0.3 & 0.3 & 0.4 & 882 \\
\hline Condom & 9.6 & 18.0 & 17.2 & 29071 \\
\hline Injectable & 6.7 & 12.3 & 12.5 & 23317 \\
\hline Other & 11.8 & 18.1 & 20.4 & 40477 \\
\hline Not using & 68.3 & 44.9 & 44.1 & 231357 \\
\hline Total & $\mathbf{3 2 3 9 7 2}$ & $\mathbf{8 4 9 3}$ & $\mathbf{3 0 3 6}$ & $\mathbf{3 3 5 5 0 1}$ \\
\hline
\end{tabular}

*permanent include male and female sterilization

The proportion of women not using any family planning method is higher among women who never had an abortion compared to women who ever had an abortion. Other methods are more used followed by condom among all women.

The family planning methods are used pattern is same for women who never had an abortion, had at least one abortion and had more than one abortion.

Table 2 is showing the logistic regression results of likelihood estimates of contraceptive use among currently married women aged 15-49 years after an abortion by background characteristics. Contraceptive use among women is significantly higher in the age group 25-34 (OR 1.321) compare to women in the age-group 15-24. 
Contraceptive use significantly increased with the increase in the number of children.

Table 2: Logistic regression results, likelihood estimates of contraceptive use among currently married women aged 15-49 years after abortion by background characteristics of, India.

\begin{tabular}{|c|c|c|c|}
\hline \multirow{2}{*}{$\begin{array}{l}\text { Background } \\
\text { Characteristics }\end{array}$} & \multirow{2}{*}{$\operatorname{Exp}(\beta)$} & \multicolumn{2}{|c|}{$95 \%$ C.I for exp ( $\beta$ ) } \\
\hline & & Lower & Upper \\
\hline \multicolumn{4}{|l|}{ Age } \\
\hline \multicolumn{4}{|l|}{$15-24 \AA$} \\
\hline $25-34$ & $1.321 *$ & 0.985 & 1.771 \\
\hline $35-49$ & 0.988 & 0.645 & 1.514 \\
\hline \multicolumn{4}{|c|}{ Number of Children } \\
\hline \multicolumn{4}{|c|}{ No child $\AA$} \\
\hline 1 & $11.879 * * *$ & 6.623 & 21.305 \\
\hline $2-3$ & $13.019 * * *$ & 6.968 & 24.324 \\
\hline \multicolumn{4}{|c|}{ Place of abortion } \\
\hline \multicolumn{4}{|l|}{ Public $₫$} \\
\hline Private & 0.878 & 0.668 & 1.153 \\
\hline Other & 1.122 & 0.716 & 1.759 \\
\hline \multicolumn{4}{|c|}{ Place of residence } \\
\hline \multicolumn{4}{|l|}{ Rural® } \\
\hline Urban & $1.694 * * *$ & 1.311 & 2.191 \\
\hline \multicolumn{4}{|l|}{ Religion } \\
\hline \multicolumn{4}{|l|}{ Hindu $®$} \\
\hline Muslims & 1.257 & 0.853 & 1.852 \\
\hline Others & 1.084 & 0.671 & 1.750 \\
\hline \multicolumn{4}{|l|}{ Caste/tribe } \\
\hline \multicolumn{4}{|l|}{ Scheduled caste ${ }^{\circledR}$} \\
\hline Scheduled tribe & 1.106 & 0.613 & 1.994 \\
\hline $\begin{array}{l}\text { Other backward } \\
\text { class }\end{array}$ & 0.787 & 0.546 & 1.135 \\
\hline Other castes & 1.082 & 0.746 & 1.571 \\
\hline \multicolumn{4}{|l|}{ Wealth index } \\
\hline \multicolumn{4}{|l|}{ Poor ${ }^{\circledR}$} \\
\hline Not poor & $1.462 *$ & 0.990 & 2.160 \\
\hline \multicolumn{4}{|c|}{ Couples education } \\
\hline \multicolumn{4}{|l|}{ Both illiterate® } \\
\hline $\begin{array}{l}\text { Only husband } \\
\text { literate }\end{array}$ & 0.934 & 0.524 & 1.662 \\
\hline $\begin{array}{l}\text { Only wife } \\
\text { literate }\end{array}$ & 1.747 & 0.759 & 4.020 \\
\hline Both literate & $2.196 * *$ & 1.256 & 3.839 \\
\hline \multicolumn{4}{|l|}{ Mass media } \\
\hline \multicolumn{4}{|l|}{ No exposure ${ }^{\circledR}$} \\
\hline Exposure & $1.451 * *$ & 1.099 & 1.916 \\
\hline
\end{tabular}

The women having one child and two or more children increased the likelihood of contraception use by 11.88 and 13.02 odd times respectively. According to the place of residence, the women residing in the urban area are 1.694 odd times more likely to use contraception than the women residing in the rural area. Women belonging to the non-poor section are 1.462 odd times more likely to use contraception than their counterpart of poor is.
However, according to couple education, contraceptive use is high among the couple when both are literate (OR 2.196) compare to a couple when both are illiterate. The women exposed to mass media are 1.451 odd times more likely to use contraception compare to the women not exposed to mass-media. Interestingly, other factors such as place of abortion, religion, and caste/tribal were not found to be associated with the use of contraceptive method.

Table 3 portrays the percentage distribution of reasons for not using contraceptive method among currently married women aged 15-49 years who had induced abortion by background characteristics of women. Women reported method-related reason $(33.9 \%)$ followed by fertility related reason $(32.5 \%)$ as the major barrier for not using a contraceptive method.

Table 4 presents the future contraceptive method preference among currently married women aged 15-49. Women preferred permanent method over temporary method for both using within 1-2 years and for more than 2 years. However, more than seventy percent of women are undecided on using the temporary method in future.

\section{DISCUSSION}

The present study has shown postabortion contraceptive behaviour among currently married women. The study reavealed that the women aged 25-34 are more likely to use contraceptive methods than the women aged between 15-24. This finding is supported by the study conducted on 2326 public-sector health facilities in eight African and Asian countries. ${ }^{16}$ The higher the number of children, the higher the likelihood of using contraception. The likelihood of contraception use increases if the women belonging to non-poor section compare to its counterpart poor. Literacy among both husband and wife increases the contraception use after abortion among women. Exposure to mass media is also playing a determining factor of use of contraception after abortion among women.

Method related reasons are the leading cause for not using postabortion contraception. The higher percentage of currently married women preferred permanent methods for both using within 1-2 years and more than 2 years. More than seventy percentage of currently married women are undecided on using the temporary method in future. Post-abortion contraceptive, a critical component of comprehensive abortion care, includes contraceptive counseling and provision of methods.

The post-abortion contraceptive is still being treated as part of family planning services rather than as a component of maternal health. This perspective ignores the potential risks to the maternal mortality and morbidities associated with narrow pregnancy intervals and results in a missed opportunity for intervention. 
Table 3. Percentage distribution of reasons for not using contraceptive method among currently married women aged 15-49 years who had induced abortion by background characteristics, India.

\begin{tabular}{|c|c|c|c|c|c|}
\hline $\begin{array}{l}\text { Background } \\
\text { characteristics }\end{array}$ & Infrequent sex & $\begin{array}{l}\text { Fertility } \\
\text { related reason }\end{array}$ & $\begin{array}{l}\text { Religious } \\
\text { reason }\end{array}$ & $\begin{array}{l}\text { Method related } \\
\text { reason }\end{array}$ & Total number \\
\hline \multicolumn{6}{|l|}{ Age } \\
\hline $15-24$ & 10.9 & 28.0 & 23.2 & 37.9 & 119 \\
\hline $25-34$ & 22.5 & 35.3 & 11.2 & 31.0 & 329 \\
\hline $35-49$ & 20.7 & 35.3 & 11.2 & 31.0 & 174 \\
\hline \multicolumn{6}{|l|}{ Number of Children } \\
\hline No child & 21.4 & 35.7 & 3.6 & 39.3 & 16 \\
\hline 1 & 18.6 & 34.2 & 16.3 & 30.9 & 251 \\
\hline $2-3$ & 20.7 & 31.1 & 12.2 & 36.0 & 355 \\
\hline \multicolumn{6}{|l|}{ Place of abortion* } \\
\hline Public & 17.5 & 34.0 & 15.7 & 32.8 & 193 \\
\hline Private & 21.6 & 32.8 & 10.9 & 34.7 & 320 \\
\hline Other & 20.9 & 30.2 & 15.5 & 33.3 & 77 \\
\hline \multicolumn{6}{|l|}{ Place of residence } \\
\hline Rural & 21.8 & 32.8 & 12.2 & 33.3 & 485 \\
\hline Urban & 15.8 & 32.2 & 13.7 & 33.9 & 137 \\
\hline \multicolumn{6}{|l|}{ Religion } \\
\hline Hindu & 21.9 & 31.3 & 12.8 & 34.1 & 498 \\
\hline Muslims & 10.9 & 35.6 & 17.2 & 36.2 & 93 \\
\hline Others & 14.3 & 44.6 & 17.9 & 23.2 & 31 \\
\hline \multicolumn{6}{|l|}{ Caste /tribe* } \\
\hline Scheduled caste & 22.8 & 34.9 & 15.3 & 27.0 & 105 \\
\hline Scheduled tribe & 17.3 & 24.0 & 20.0 & 38.7 & 45 \\
\hline Other backward class & 19.4 & 32.7 & 12.4 & 34.8 & 310 \\
\hline Other castes & 20.1 & 31.8 & 12.4 & 35.8 & 152 \\
\hline \multicolumn{6}{|l|}{ Wealth index } \\
\hline Poor & 23.5 & 25.0 & 14.2 & 37.3 & 212 \\
\hline Not poor & 18.2 & 35.7 & 13.6 & 32.4 & 410 \\
\hline \multicolumn{6}{|l|}{ Couples education } \\
\hline Both illiterate & 17.5 & 19.1 & 15.8 & 47.5 & 108 \\
\hline Only husband literate & 22.5 & 33.6 & 12.4 & 31.6 & 184 \\
\hline Only wife literate & 26.5 & 44.1 & 8.8 & 20.6 & 19 \\
\hline Both literate & 18.7 & 35.7 & 14.1 & 31.6 & 311 \\
\hline \multicolumn{6}{|l|}{ Mass media* } \\
\hline No exposure & 24.4 & 27.8 & 12.0 & 35.7 & 164 \\
\hline Exposure & 15.2 & 35.4 & 14.3 & 35.1 & 225 \\
\hline Total & 19.8 & 32.5 & 13.8 & 33.9 & 622 \\
\hline
\end{tabular}

*Missing value

Table 4: Percentage distribution of currently married women aged 15-49 years not using contraceptive by contraceptive method they prefer to use in future, India, DLHS-3, 2007-2008.

\begin{tabular}{|lclll|}
$\begin{array}{l}\text { Future } \\
\text { contraceptive } \\
\text { method }\end{array}$ & $\begin{array}{l}\text { 1-2 } \\
\text { years }\end{array}$ & $\begin{array}{l}\text { More } \\
\text { than 2 } \\
\text { years }\end{array}$ & Undecided & $\begin{array}{l}\text { Total } \\
\text { No. }\end{array}$ \\
\hline Permanent & 45.0 & 9.0 & 46.0 & 478 \\
\hline Temporary & 25.3 & 2.6 & 72.1 & 88 \\
\hline Total & $\mathbf{4 2 . 0}$ & $\mathbf{8 . 0}$ & $\mathbf{5 0 . 0}$ & $\mathbf{5 6 6}$ \\
\hline
\end{tabular}

The study added some empirical finding on the contraceptive used among women who had induced abortion. This study reveals that still there is a need to focus on the unmet need for the modern method of contraception in India. The government should increase the methods availability, train providers on newly introduced methods, integrate evidence-based guidelines into contraceptive recommendations, and educate women and their communities about the safety and efficacy of new contraceptive methods. There is need to draw attention to the side effects of repeated induced abortion among women.

However, for understanding these issues in a comprehensive way, Qualitative in-depth studies on clinical examination need to be conducted. 


\section{ACKNOWLEDGEMENTS}

The authors would like to thank NFHS for allowing the dataset for this study.

Funding: No funding sources

Conflict of interest: None declared

Ethical approval: The study was approved by the Institutional Ethics Committee

\section{REFERENCES}

1. World Health Organization. Unsafe Abortion: Global and Regional Estimates of the Incidence and Mortality in 2008. 6th ed. Geneva, Switzerland: Department of Reproductive Health and Research, World Health Organization; 2011. [Accessed June 18, 2014]. Available from: http://www.who.int/reproductivehealth/publications/ unsafe_abortion..

2. Mundigo, AI. 'Mortality and morbidity due to induced abortion', paper presented at the seminar on Measurement of Maternal and Child Mortality, Morbidity and Health Care: Interdisciplinary Approaches, International Union for the Scientific Study in Population, Cairo. 1991;47.

3. Rahman A, Katzive L, Henshaw SK. A global review of laws on induced abortion, 1985-1997. Int Fam Plann Persp. 1998;24(2):56-64.

4. Ministry of Health and Family Welfare, Government of India. Family Welfare Programme in India year book. New Delhi: Department of Family Welfare. 2001. Available from: http://s3.amazonaws.com/zanran_storage/mohfw.nic. in/ContentPages/1380486224.pdf

5. Duggal R, Ramachandran V. The abortion assessment project-India: key findings and recommendations. Reprod Health Matters. 2004;12(24):122-9.

6. Banerjee SK, Andersen KL, Warvadekar J. Pathways and consequences of unsafe abortion: A comparison among women with complications after induced and spontaneous abortions in Madhya Pradesh, India. Int J Gynecol Obstet. 2012;118:S113-20.
7. Banerjee SK, Manning V. Post-abortion contraception: A neglected public health domain. In Asian Population Association Conference, New Delhi, India 2010 Nov.

8. Visaria L, Ramachandran V, Ganatra B, Kalyanwala S. Abortion in India: emerging issues from qualitative studies. Econo Politic Weekly. 2004;20:5044-52.

9. Stillman M, Frost JJ, Singh S, Moore AM, Kalyanwala S. Abortion in India: a literature review. New York: Guttmacher Institute. 2014:12-4.

10. Rasch V, Yambesi F, Massawe S. Medium and longterm adherence to postabortion contraception among women having experienced unsafe abortion in Dar es Salaam, Tanzania. BMC Pregnancy and Childbirth. 2008;8(1):32.

11. McDougall J, Fetters T, Clark KA, Rathavy T. Determinants of contraceptive acceptance among Cambodian abortion patients. Studies Fam Plann. 2009;40(2):123-32.

12. Cohen SA. Facts and consequences: legality, incidence and safety of abortion worldwide. Guttmacher Policy Rev. 2009;12(4):2-6.

13. Melkamu Y, Enquselassie F, Ali A, Gebresilassie H, Yusuf L. Assessment of quality of post abortion care in government hospitals in Addis Ababa, Ethiopia. Ethiop Med J. 2005;43(3):137-49.

14. Aquino EM, Menezes G, Barreto-de-Araújo TV, Alves MT, Alves SV, Almeida MD et al. Quality of abortion care in the Unified Health System of Northeastern Brazil: what do women say?. Ciencia Saude Coletiva. 2012;17(7):1765-76.

15. Sheelamoni A, Nair MK, Remadevi S. Contraceptive behaviour of abortion seekers-a case control study. J Obstet Gynecol India. 2007;57(5):0-266.

16. Benson J, Andersen K, Brahmi D, Healy J, Mark A, Ajode A et al. What contraception do women use after abortion? An analysis of 319,385 cases from eight countries. Global Public Health. 2016;19:1-6.

Cite this article as: Kumari N, Dutta M, Shekhar C. Post abortion contraceptive behavior among Indian women. Int J Reprod Contracept Obstet Gynecol 2017;6:2021-5. 